\title{
Sino-African Relations: Emerging Concerns and Dynamics
}

\author{
Knocks Tapiwa Zengeni
}

Abstract

The objective of this article is to demonstrate that one of the most significant consequences of the growth of China-Africa relations is the positioning of the African continent as a possible theatre for US-China geo-political rivalry. The interpretative approach adopted in this essay involves a comprehensive review of extant literature, and draws on recent data to highlight China's economic forays into Africa and the attendant implications. Undeniably, Africa's strategic minerals are of great value to both competing global powers, that is, the United States and China. Interestingly, China's presence in Africa has been bolstered by its state-capitalist model which has captivated and convinced most African leaders into believing that this alternative development paradigm might be the answer to Africa's long quest for economic growth. To many African leaders whose regimes are mainly pseudo-democracies, the Chinese model which delivers economic growth without embracing democracy has become an attractive option vis-à-vis the Western model which is predicated on unpopular conditionalities of good governance and respect for human rights. While the emergence of China in Africa has been welcomed in the continent, it is equally true that some concerns and fears are emerging over the growing presence of China in Africa. Some of these concerns include the reversal of the democratization agenda in some African countries; the unequal trade relations between Africa and China; environmental questions on Chinese investments; and fears of a re-packaged form of new colonialism. More importantly, most African countries are apprehensive about the growing tensions between China and the US over Africa which might lead to a new 'Scramble for Africa' and the re-emergence of proxy conflicts on the continent.

Keywords: China, Africa, United States, democratisation, trade.

\section{Introduction}

Until the re-entry of China in the past decade (and to some extent by Russia, Brazil, and India), the natural resources of Africa were exploited almost exclusively by Western countries. Both bilaterally and through multilateral agreements and mechanisms, Western countries provided substantial development aid to African countries, which in return, continued to supply their natural resources to the Western markets. Although Africa is a continent comprising 54 sovereign states, in this paper, however, the continent is treated as a monolith entity in order to appreciate China's grand foreign policy towards Africa. As China and other re-emerging global economic players grow their economies, it is obvious 
that they will not attain their goals of being dominant economic giants without access to the vast and untapped natural resources of Africa. Clearly, the strategic aims of these rising countries like China is to achieve a standard of living of their citizens that is comparable to those enjoyed by citizens of Western counties in North America, Europe as well as Japan. Notably, China and Africa have been trading partners for centuries, but the former's reentry into Africa in the 21st century has resulted in a qualitative change. China is now Africa's largest trading partner. According to Ng (2012, p. 1), China's bilateral trade with Africa has grown more than 16 times between 2000 and 2011. In 2011 trade between China and Africa reached US\$106 billion, a figure the US and its Western partners are unable to match currently due to a number of reasons, notably, economic recession in their respective economies. For instance, the United States (US) Census Bureau indicate that the US trade with Africa in 2011 was just under US\$126 billion $(\mathrm{Ng}, 2012$, p. 1). Interestingly, given these differences, the US and its Western allies have focused on commitments in other forms in their relations with African countries, especially their stated support for good governance and democratisation.Currently, $80 \%$ of China's imports from Africa are from the extractive sector, and the most significant import is oil (Ramburuth, Buatsi, \& Owusu, 2010, p. 155). Meanwhile, China's strategic intentions in Africa appear to be divided between acting as a facilitator for Africa's development and an extractor of its resources. Unsurprisingly, Western criticism of China's expansion into Africa has also deepened. The key concern for the US-Western alliance perspective is the prevailing uncertainty in ascertaining Chinese strategic intentions, actions and responses to potential crises centred on Africa as well as to the democratisation agenda. However, so far, Western criticisms of China's engagement with Africa seem to have fallen on deaf ears. In other words, it has failed to make an impact on Africa because the Western model of aid-driven development underpinned by the democratization and good governance agenda has been an unqualified success in the eyes of most African countries. On its part, China has adopted a 'soft diplomacy' strategy in its pursuit of global expansion and growth. The main drivers of this expansion include supporting the increased presence of China's state owned enterprises (SOEs) and privately owned enterprises in Africa. Clearly, China's engagement with Africa in the past decade has brought benefits to Africa's development.However, in weighing the benefits of China's penetration in Africa, African countries must consider issues of sustainability for long term development and develop strategies to leverage the benefits of their rich resources, without being too dependent on external players for their development (Ramburuth, Buatsi, \& Owusu, 2010, p. 155).Certainly, this should also include exploiting the emerging fissures and schisms between the US and China over their untapped wealth to their own advantage. After all, history teaches us that there are no permanent friends or enemies, only permanent interests.

\section{Background of Sino-African Relations}

Africa and China have a long tradition of economic and cultural ties that span centuries. It needs to be emphasized that Sino-African relations are not new and go far back as the Ming Dynasty in the fifteenth century, when the ancient Chinese explorer, Zheng He sailed the 
coast of East Africa (Ramburuth, Buatsi, \& Owusu, 2010, p. 156). His intention and mission was to win the allegiance and support of people from distant lands, an act thought to have brought prestige and recognition to the emperor. In the 1960s, the then Chinese premier Zhou En lai made several diplomatic trips to Africa in which he reinforced the notion of friendship, declaring that his delegation essentially came "to renew acquaintance with old friends"(Snow,1988, p. 75). Interestingly, Zhou's visits put in place the Five Principles of Peaceful Co-existencethat echo throughout China's current stated Africa policy which was released in January 2006, These principles are "mutual respect for each other's territorial integrity; non-aggression; non- interference in each other's internal affairs; equality and mutual benefit; and peaceful coexistence" (Taylor, 2006, p. 939). Notably and more importantly, non-interference in state sovereignty and freedom from hegemony has been a constant theme of Chinese foreign policy since the Five Principles of Peaceful Coexistence were formulated in the 1950s as the basis of Beijing's foreign relations. It should also be pointed out that these principles continue to be demonstrated in Chinese dealings, such as highly publicized forums such as the Forum on China-Africa Cooperation (FOCAC) which is held every three years since 2000 .

Importantly, as is evident in the foregoing, while Sino-African relations have a historic basis, one built on the principle of 'non-interference', the economic motif is now arguably dominant. Notably, China's 21st-century re-entry into Africa contrasts sharply with the Maoist ideologist policy of the 1960s and 70s that nurtured socialist revolutionary movements across Africa. In recent years, the economic affair between China and African countries has since deepened and blossomed. Apparently, this new wave of Sino-African relations is dominated by China's particular focus on oil and other extractive natural resources (Taylor, 2006; Ramburuth, Buatsi, \& Owusu, 2010). The risingeconomic ties have intensified with an exponential growth in trade and investment across most African countries. Not surprisingly, China eclipsed the US as Africa's largest trading partner in 2009. Specifically, African countries have been consumers of China's global strategies that are driven by an insatiable appetite for resources to fuel the latter's economic growth. China's aggressive search for resources is complemented by targeting of foreign markets for their products, strategic growth of outward FDI, and implementation of its 'soft diplomacy' policy to underpin and expand global growth.

Despite China's long-term interest in Africa, its recent re-entry into Africa raises major questions concerning contemporary and future Sino-African relations. One fundamental question, of course, is: What factors contributed to China's recent successes in Africa? Certainly, China's success in Africa has been due to a number of factors. This essay suggests that a primary cause of that success can be attributed to the basic compatibility between Chinese foreign policy objectives and the goals of many African states.

\section{Understanding China's Success in Africa}

This section represents an attempt to analyze China's success in Africa, through a critical examination of Chinese policy objectives and Chinese tactics in response to African goals. 
By examining Chinese activities in Africa over the past decade, certain basic objectives become noticeable. Not all of the objectives have been stressed with equal passion nor have they always been emphasized at the same time.It needs to be stated that China's increasing engagement with Africa is a manifestation of the remarkable transformation of the country's foreign policy in the aftermath of its economic miracle. With China continuing its dynamic economic growth, it is evident that one major outcome of this development has been China'sdesire to seek a more active role in the international system. Clearly, the Beijing government has expanded and intensified its bilateral relations throughout the world, has joined regional bodies dealing with security and economic issues, and has extended its involvement in multilateral international organisations.

Without doubt anti-imperialism has constituted a major theme in the foreign policy of China since the 1950s. Within the context of China's African policy, anti-imperialism has served the primary purpose of exposing the imperialistic character of United States policy (including of its Western allies). This characterization of the West has been vindicated and verified by recent actions by the US and its allies, particularly the occupation of Iraq in 2003 and the role they played in the toppling of Libya's Gaddafi (despite his weaknesses Gadaffi was hugely popular within Sub-Sahara Africa). Such actions possibly constituted excellent examples on how imperialists suppress ruling regimes in the developing world (including in Africa).By relating contemporary United States foreign policiesto Africa and the developing world, past and present, China has sought to create in African minds an image of the United States as the new imperialist, the successor to the old European powers. To bolster its foreign policy objectives, China is constantly reiterating the mantra of developing world solidarity (within the context of Africa this form of solidarity is epitomized by FOCAC). It is therefore not surprising that China continue to emphasise the common historical heritage of exploitation suffered by China and Africa at the hands of the West.

Another theme that dominates China's Africa policy has been to cite shared problems of nation-building and Western interference. China has used such common interests or concerns to call for greater cooperation between the two regions in their quest to defeat Western' imperialism. The fierce reactions of Western countries to the student massacre in Tiananmen square in June 1989, including an arms embargo imposed by the US and the European Union (EU), and persistent Western criticism of China's human rights record, triggered Beijing's policy shift to seek closer ties with non-Western countries in an effort to build coalitions to shield Beijing as well as developing countries from Western criticism. Since many African leaders are themselves currently under growing domestic and external pressure to liberalise their political systems, "they are more than willing to go along with China's claims that Western demands for democracy and the respect for human rights amounted to thinly veiled imperialistic manoeuvres intent on interfering in the domestic politics of developing states, and undermining their stability and progress at large" (Tull, 2006, p. 461). Arguing along similar lines Ian Taylor (2006) observes that China's renewed interest in Africa coincided with an upsurge of western interest in promoting liberal democracy and human rights in the post Cold War era. According to Taylor the democratization agenda is phenomenon 
that has threatened the entrenched position of incumbent presidents across the continent of Africa. As noted by Philip Snow cited in Taylor (2006), "both Chinese and African elites like to adopt the posture of having experienced-and continuing to face-the common enemies of imperialism and "neo-imperialism" (p. 939). Expertly, China has tapped into African suspicion and fears of Western norms of human rights and liberal democracy, by asserting that values such as 'economic rights' and 'rights of subsistence' are the main priority of developing countries and take precedence over personal, individual rights as conceptualized in the West (Taylor, 2006, p. 939). Not surprisingly, this perspective is shared by many African leaders

More importantly, China's desire to gain recognition and assert leadership among the developing world must be seen as another foreign policyobjective that is compatible with African goals. Given their numerical weight in international organisations, African states will play an important role in the Chinese ruse. Gauging the relations between developing and developed countries in the context of a North-South conflict, this discourse served as a powerful glue whereby China is succeeding to construct a common identity with African states vis-a-vis the paternalistic and arrogant West. The continuous harassment of African governments by the West to embrace neo-liberal economic policies which have a record of failure has presented China with a strategic opportunity to penetrate Africa. With these considerations in mind, China moved swiftly to increase its assistance to African countries. As a result, China's foreign policy as a whole is by and large viewed by African countries to be more dynamic, constructive, flexible and helpful when compared with Western policies. Undoubtedly, the increased cooperation between China and African countries would greatly enhance China's international status and prestige.

Against the background of China's policy objectives in Africa, let us examine briefly China's response to fundamental African goals: political independence, and economic development. If there exists one basic idea subscribed to by all Africans, that idea has been political independence or its alter ego sovereignty. Within the context of African states, political independence entails independence both from direct foreign rule in all its manifestations and independence from African rule by non-Africans or external forces. China has historically supported African independence movements, and presently resists the Western regime change agenda aimed at some ruling regimes in the developing world. Furthermore, more African countries are aware that independence does not always mean the end of foreign rule, let alone foreign influence. Indeed, history teaches us that imperialists have adopted a vast variety of new policies and methods to perpetuate their domination over developing countries. Some of these strategies include the 'imposition' of unfavourable economic partnership agreements, the establishment of military bases (as in former French colonies in West Africa), the use of economic technical assistance programs and others. These policies, known collectively as neocolonialism, are now generally regarded as more vicious and more treacherous than the old colonialism. Unsurprisingly, the policies are seen as seriously jeopardizing African states. By calling upon most African states to continue their anti-imperialism struggle and to achieve 'true political independence', China's image as a constructive 'Big Brother' is taking shape. 
China, in short, shares her anti-imperialism and respect for sovereignty objectives with most African states. It is hardly surprising that her attempts to induce African states to accept her world view have met little resistance. As indicated earlier, the fact that many African leaders are themselves under growing domestic and external Western-inspired pressure to liberalise their political systems, they are more than willing to go along with China's viewpoint that Western demands for democracy and the respect for human rights are disguised imperialistic manoeuvresbent on undermining the independence, stability and progress of developing countries. This implies that African and Chinese policy makers have a completely common interest in the present international system. Despite misgivings and concerns about China's Africa policy, the majority of African countries seem to believe that it is a worthwhile strategic partner that is willing to help Africa achieve its own goals of national development and total independence. To what extent these African countries will tie their economies with that of China depends, in no small measure, depend on the extent to which alternative economic opportunities are made available to them. So far the Western models of development assistance have come short. To put it differently, these models have been unattractive vis-à-vis China's model of mutual benefit.

\section{Impact of China's Engagement Policy in Africa: The Positives}

\section{Rebalancing the West}

China's rapid growth and increased integration with the global economy since the late 1970s have significant economic impacts and political implications for Africa. China's rapid rise has compelled some African countries to court her in order to counter Westernpaternalistic attitude in the region. The US and its allies have been operating arrogantly towards African countries. The economic partnership agreements between African countries and Western countries are skewed heavily in favour of Western interests. These packages contained conditionalitieswhich impose conditions on developing African countries that are nearly always unbearable and sometimes even politically unacceptable. For example, the United States' Africa Growth and Opportunity Act (AGOA) authorizes the US President to designate Sub-Saharan countries as eligible to receive benefits of AGOA if they are determined to have established, or are making continual progress toward establishing the following conditions "market based economies; the rule of law and political pluralism; elimination of barriers to US trade and investment; protection of intellectual property; efforts to combat corruption; policies to reduce poverty; ... protection of human rights and worker rights (Section 104 of the AGOA). Some of these liberal prescriptions like the Washington Consensus inspired structural adjustment programmes (SAPs) forced African countries to abandon export taxes and quantitative restrictions on raw materials, and subsidies. Consequently, these measures have been less friendly and detrimental to Africa's development needs.For instance, the removal of export taxes, not required under World Trade Organisation (WTO) rules, has incensed African leaders and policy makers because the elimination of export taxes has meant deindustrialization and the loss of jobs in the export sector. Put differently, Western 
development models in Africa promoted one-sided and ultimately exploitative relationship (Schuftan, 1998, p. 16). Thus, Western policy towards Africa has been treated as one more weapon in the arsenal of global imperial politics promoting the status quo, namely, the exploitation of Africa. However, with the entry of China and other rising countries like India, African countries are now enjoying much favourable economic partnership agreements which provide low interest loans, concessional assistance and infrastructure development. For African policy makers, the Chinese or Asian model is perceived as favourable and superior to European and United States free market approaches, which were strong on rhetoric but weak on infrastructure and aid. To illustrate the point further, China has been able to execute a better coordinated foreign investment drive aimed at developing Africa's poor infrastructural base. It is therefore scarcely surprising that China's development assistance which largely comprise of in-kind infrastructural development projects has appealed to African policy makers because of its tangible benefits in overcoming developmental hindrances. On the other hand, Western donors have continued to focus their energies on championing issues with intangible benefits such as human rights and good governance which have so far failed to bring any meaningful or real economic growth to the continent. Furthermore, Western manoeuvres in Africa, particularly the aid policies have not had much success. In other words, the re-emergence of China in African affairs in the 21 st century will ultimately compel Western countries to revise their economic and political strategies with African countries if they want the same access to African energy, mineral and agricultural products $(\mathrm{Ng}, 2012)$. They might have to behave a bit more oriental by making policies that encourage infrastructure development in Africa. The rise of China is undoubtedly a significant factor that could benefit Africa as the great powers compete with each other to gain access to Africa's untapped natural resources.

\section{Economic Benefits}

China's active promotion of economic interaction with Africa has significantly contributed to the impressive growth rates of trade and investment. In institutional terms, this has been demonstrated by the establishment of the Forum on China-Africa Cooperation (FOCAC) in 2000. What are the factors behind the Chinese-African enhanced trade relations? The massive export of cheaper goods to Africa is part of the story. According to Tull (2006), due first to its large and cheap labour force, China offers low-price export goods such as textiles and clothing, electronic devices and machines, which find a huge and soaring demand in vast parts of Africa, which are characterized by acute poverty (p. 464). Whilst Africa benefits from cheaper products from China, there is growing concern about the quality of the products and the overall implications for local manufacturing sector and employment. For instance, it is pointed out that the disconcertingly high percentage of China's textile, apparel and footwear exports to Africa have had a negative impact on the local industry and small business in Africa (Ramburuth, Buatsi and Owusu (2010, p. 161). More specifically, cheaper and affordable Chinese products have created situations where local firms cannot compete with the lower-priced imported products, leading to mounting social problems like closures and unemployment. So, the question that arises is whether African 
policy makers are prepared to raise such problems in their dealings with China. To put it differently, Africa's political leadership must insist on regulation on foreign investment which prohibits a dependency syndrome. Such policy interventions avoid a pure trade dependency relationship similar to that developed earlier between the developed West and Africa. In a dependency relationship, finished goods from the industrialized countries are exported to underdeveloped countries in return for raw materials to be processed for export back to these developing markets. This has the spiral effect of keeping the underdeveloped world underdeveloped and concentrating capital in the developed world which grow richer through manufactuiring value-added (finished) products, which the underdeveloped world becomes dependent on (Brahm, 1996, p. 8). Naidu (2007) cited in Ramburuth, Buatsi and Owusu (2010) argues that larger and powerful African states like South Africa can influence the trade agenda. To bolster her argument Naidu cites an example of the Beijing government making concessions and imposing restraints on clothing and textile exports to the South African market (p. 161). Furthermore, at the in July, 2012 at the fifth Forum for ChinaAfrica Co-operation, the south African President Jacob Zuma created something of a stir when he described the unequal trade relations between Africa and China as unsustainable (Mail \& Guardian, 2012, July 27), further underlining the bargaining power of powerful African states. Zuma also remarked that "Africa's past economic experience with Europe dictates a need to be cautious when entering into partnerships with other economies," (Mail \& Guardian, 2012, July 27). As exemplified by this discussion, it is uncertain whether smaller and weak African states can have the same expectation or clout, implying, therefore, the need for stronger African leadership and unity to ensure 'real' mutual beneficits as enshrined in the Chinese Five Principles of Peaceful Co-existence.

Enhanced Chinese economic interest in Africa is also reflected in the fact that China's demand for energy resources has inflated prices, bringing a windfall to African states' income. According to Taylor the country's exceptionally robust economic growth since the late 1970s has stimulated a huge upsurge in its demand for oil, for example, " between 1995 and 2005 China's oil consumption doubled to 6.8 million barrels per day" (2006, p. 943). Furthermore, China became a net importer of oil in 1993, and for the foreseeable future oil will be the only primary energy fuel capable of fulfilling China's growing needs in both transportation and industry. It is therefore not surprising that since China became a net oil importer, its appetite for oil supplies has escalated massively as reflected in Beijing's increased presence in Africa's oil sector. Partly as a result of China's interest in Africa, particularly in African oil and other strategic natural resources the continent's growth rate has increased, touching 4.5 per cent in 2004. Importantly, the strong growth in price receipts (revenue) from bilateral trade between China and Africa in the last decade or so is another feather in the cap in trade relations between the two. Of course, the key issue is what African leaders do with this sudden influx of revenue due to growing economic relations with China's. How do governments use this development and the increased engagement by China to benefit the ordinary people and promote development in an environment constrained by elite-driven patronage and extravagance. 


\section{Infrastructure Development}

A major impediment for sustained economic development in Africa is the poor infrastructure that is evident in most African countries except for a few former settler colonies like South Africa and Zimbabwe. In this area, most African countries have poor road networks including roads, railways and ports; poor communications systems; and erratic power supplies (Ramburuth, Buatsi, \& Owusu, 2010, p. 159). However, in recent years, China's investment in Africa's infrastructure development has made significant contributions in this sector(Ng, 2012). According to a World Bank report by Forster and others (2008), entitled Building Bridges: China's Growing Role as Infrastructure Financier for Africa, China's commitments to infrastructure projects in 35 African countries rose from less than US\$1 billion per year between 2001-03, to about US\$1.5 billion in 2004-05, and reached a peak of US\$7 billion in 2006. It is interesting to note that China's growing role as infrastructure investor in Africa has benefited both China and Africa. Chinese construction firms have benefited from this infrastructure developments drive since most of the construction machinery and equipment are sourced from China. More importantly, China's state-owned enterprises and more recently, its emerging private sector firms, are the main drivers of the infrastructure projects.Specifically, strategic sectors that have been targeted include power (mainly hydropower), information technology and telecommunications and transport (mainly railways). As noted by Ramburuth, Buatsi and Owusu, (2010), China is responsible for rebuilding $1,350 \mathrm{~km}$ of rail throughout the continent, $1,600 \mathrm{~km}$ of new rails and increasing total hydropower in Sub-Saharan Africa by an impressive 30\% (p. 159). Clearly, There is no doubt that China's policy on infrastructure building has yielded many benefits and comparative advantage to African states.China's investment in Africa's crumbling infrastructure is needed and is welcomed by most. It may be argued that the neglect of the infrastructural sector by Western investors and donors has presented China with a strategic opportunity to fill the gap and firmly establish itself in Africa. Notably, throughout Africa, Chinese firms are occupied in building hospitals, dams, government offices and stadiums and refurbishing facilities abandoned by western companies (Taylor, 2006, p. 951). There is, however, growing concern about the sustainability of the pace and cost of infrastructure building in the current global economic climate. Some observers suggest that China may be tempted to modify aspects of its 'soft' policies by driving harder bargains with its African partners, as the global financial meltdown intensifies (Polgreen, 2009).

As indicated in the preceding discussion, it is evident that that there are structural differences between China's African engagement policy and the Western model that have fundamentally shaped the nature of relations between these parties, in which China currently has the advantage. With a growing list of African countries rapidly developing as a result of China's pragmatic imperatives and initiatives of development, the US and its Western partners need to soul search in order to regain and retain their foothold in Africa.

\section{Problematizing China's Africa Policy}

Any analysis of China's Africa policy needs to be balanced and avoid the hyperbole that has characterized some accounts in extant literature. A closer look of China's Africa policy 
seems to suggest that it may be a double-edged sword. Certainly,in the short term, China's trade with and investment in Africa appear to be helpful and beneficial to the continent in the sense that it is providing sorely needed investment that was not being offered by others, especially Western donors. As noted earlier, it is evident that China's investment in Africa's collapsing infrastructure is needed and is welcomed by most since such initiatives may trigger and stimulate African economic growth (see Ng, 2012). Put another way, China may have provided what may be seen as a low-cost developmental solution to many African countries. Nevertheless, when one looks at the long-term trajectory, concerns mount. China's Africa policy is driven by China's huge interests in African oil resources. In fact $80 \%$ of China's imports from Africa are from the extractive industries, with the key import being oil (70\%), followed by iron ore, cotton, wood and agricultural products (Ramburuth, Buatsi \& Owusu 2010,p158). It needs to be stated that, in 2006, Angola surpassed Saudi Arabia as China's largest source of crude oil imports. Like most industrialized economies, China's addiction to oil is understandable. It is interesting to note that China's pursuit of oil resources in Africa has two main strategic purposes, namely, (i) short-term acquisition of oil supplies to fulfill the growing domestic demand in China; and (ii) long-term investment as a global actor in the international oil market (Ramburuth, Buatsi, \& Owusu, 2010, p. 158). However, according to Taylor (2006), a reliance upon oil and other primary commodities is " deeply problematic for African nations wishing to avoid the typical resource curses that tend to accompany an overdependence on one particular commodity and/or to move beyond being suppliers of primary products" (p. 951). History has demonstrated that over-reliance on primary commodities such as oil tends to make African nations more vulnerable to negative price shocks which are beyond their control. One fundamental risk is that the commodity boom might give rise to a sense of complacency, which might prevent African governments from implementing the necessary policy interventions to make growth sustainable in the medium to long term through investment in human capital and infrastructure. It is hardly surprising that over-reliance on commodities such as oil threatens to make African nations even more vulnerable to negative price shocks. Furthermore, if receipts accrue from oil exports to China there is a very real temptation for the local elites not to diversify their economies. This potential risk or danger may be compounded by China's propensity to keep downstream and processing activities (value addition) within China, generally importing only pure raw materials. In this sense, a huge increase in Chinese interest in Africa's oil and extractive industries threatens to only deepen Africa's dependency.

Of equal concern, however, is China's relatively soft stancetowards the liberal norms of human rights and democracy, that are normally associated with Western African policy. As mentioned earlier, China's Africa policy is hugely informed by past measures such as the Five principles of Peaceful Co-existence which include among others: the desire to promote friendship; the intention to facilitate mutual beneficial developments; the strict adherence to the doctrine of sovereignty (including the attendant policy of non-intervention), as well as seeking to establish a stable and prosperous global community (Le Pere, 2008). Mindful of these principles,Beijing's current attitude regarding political developments in African countries (most of them viewed as repressive and undemocratic) is to view them as internal matters for the respective sovereign state. 
There are growing concerns that Beijing's current position of non-interference critically undermines African initiatives like the New Partnership for Africa's Development (NEPAD), as well as Western efforts which seek to make government and business more transparent and accountable. Indeed, a key objection to China's oil diplomacy or development assistance is that it likely to subsidise profligate and dictatorial governments. This contradiction was most graphically demonstrated in April 2006 when, on the very same day that the Dutch government was suspending nearly $\$ 150$ million in aid to Kenya because of longstanding concerns over corruption, China was busy securing an important oil exploration agreement with that same country (Taylor, 2006,p. 952). It was a telling illustration of the difference in Western and Chinese approaches toengagement with the continent. Not surprisingly, there is a strong feeling that currently China has adopted a discourse in Africa that undermines growing international norms of good governance and democracy. It appears that Beijing's current position is legitimizing human rights abuses and undemocratic practices. However, it should be pointed out that China's success in Africa has greatly benefited from its policies on sovereignty and non-interference. More so, there is no doubt that most African leaders who have been on the receiving end of Western pressures to democratize and reform have been deeply appreciative of China's stance. It remains to be seen whether the average African shares the same viewpoint. In actual fact, there is also a growing consensus among analysts (especially Western observers) that Beijing does not seem to realise that bad governance and political instability in Africa countries may sabotage the long-term possibilities of sustained Sino-African economic relations by helping to "keep Africa at the bottom of the global hierarchy, plagued by dictators and human rights abusers" (Taylor, 2006, p. 953).

Other critics view Beijing's current attitude towards African states as not qualitatively different from the 'traditional exploiters' of Africa, that is, the West. As a Kenyan report put it:

China has an Africa policy. Africa doesn't have a China policy, only a Beijing-controlled forum in which Mandarins figure out which country to take a sweet shot at. China talks of mutual trust ... The danger is that China will politely rip off Africa, just as the West did (Nation [Nairobi], 12 June 2006 cited in Taylor, 2006, p. 953).

This perspective casts China's economic engagement in Africa as basically opportunistic. Furthermore, this view suggests that the major goal of China is essentially to gain raw materials for its rising economy and new markets for its products. According to the African Forum on Debt and Development report, China is aware of the feeling among Africans that it is on the continent merely to take out raw materials and inundate the informal markets with cheap goods (Mail \& Guardian, 27 July, 2012). However, these observations do not tell the whole story. Western activities and policies in Africa and other regions are not exactly exemplary in promoting human rights, liberty and democracy. For instance,Washington's flirtations or relations with oil-rich autocratic nations such as Saudi Arabia are not guided or governed by concerns over democracy. So, in this sense, criticism of China's Africa policy is somewhat hypocritical. 
Nonetheless, attacks on China's Africa policy cannot be waved away as simply hypocritical sour grapes from the West. There is genuine concern within Africa about China's activities and intentions. To begin with, China is not immune to criticism, especially accusations of exploitation. As mentioned earlier, China's global rival the US is very keen to exploit this growing negative image of China as demonstrated in Hillary Clinton's 2012 speech in Senegal when she indicated that America's partnership with Africa is "one that adds value rather than extracts it". Earlier, during a visit to the Southern African state of Zambia in 2011, Clinton had warned of a "new colonialism in Africa, again interpreted as an indirect reference to China's engagement with Africa $(\mathrm{Ng}, 2012)$. Indeed, there is growing evidence that African citizens' resentment against the Chinese, who they perceive to be unholy partners of ruling elites, is rising. In the long run, there is a potential backlash against Beijing from frustrated and excluded local African people who do not benefit from the exploitation of Africa's natural resources. Research studies have demonstrated that Africa's quasi states and enclave economies often expend revenue from oil or mineral prices on patronage, repression of opposition groups and increased regime security (Taylor, 2006; Friedman, 2006). Furthermore, resource-rich African governments have displayed little incentive to diversify and promote development outside the resource sector. The situation is compounded by Beijing's policies to keep downstream industries that enhance value additions back in mainland China. Ironically, just like previous economic relations between Africa and the West, China's return to Africa has not abated the co-existence of affluence and underdevelopment. In other words, China's interaction with Africa is not promoting economic growth and development. African elites continue to maximize their gains at the expense of the general populace. In extreme cases like Angola (a close economic partner of both China and the West), the idea that resources should be channeled towards national development is not on the agenda of the ruling elites. It remains a figment of imagination. Ultimately, China's role in Africa may be highly problematic. By closely associating with unaccountable and corrupt governments on the pretext of non-interference, China is in danger of being associated in the local populations' eyes with exploitation, which may come back to haunt Beijing if there is ever a paradigm shift or regime change in African countries. To be fair to China, in this area, Western countries have not fared better as well,in spite of their much longer engagement with African countries. In a way, Chinese foreign policy in Africa and elsewhere is, like all other countries' foreign policies, self-serving and based on strategic and economic motives. In this respect, the Chinese government is no different from others.

\section{Challenges for the US and Its Allies}

China's rapid growth and increased integration with the global economy since the late 1970s have significant economic impacts and political implications for Africa. But clearly, USChina relations have undergone dramatic changes recently, ranging from a benign warmth in the 1970s, a deep hostility in the 1980s (over the Tiananmen Square incident), to a rapprochement in the 1990s, and a readjustment since the collapse of the Soviet Union. The 
post-cold war era has offered enormous opportunities as well as challenges to Washington and Beijing. The relationship of the two great powers has moved from the direction of 'productive relationship' to 'hostile relationship' as China flexes its muscle as an emerging global superpower. The emergence of China as a major economic and political player in the world today has led to the increasing urgency on the part of the Western countries (particularly the US) to fully grasp the implication of the rapidly transforming socioeconomic and geopolitical landscape, both regionally and globally. Of particular interest to the West is China's growing oil diplomacy in Africa, which is driven by two main goals, namely, to secure much needed oil resources for China's growing domestic needs, and to position China as a key player in the criticalglobal oil market (Taylor, 2006, p. 938).

As is widely believed, China's emergence or rise as a regional and global economic power has provided her with new political influence in the region as her trade with African countries, has been expanding rapidly in recent years. As noted earlier, China is now Africa's largest trading partner. A notable point here is that in post-colonial Africa, the United States (US) and its Western allies played a leading role in the continent's political and economic developments. The US was the natural leader because of its superpower status particularly in the aftermath of the collapse of the Communist bloc in 1989. Undoubtedly, for years, Western economic and political presence was a prominent feature in the African region. However, in the past decade, Western strong economic presence has now slowly and steadily been eroded by the rise of China. Clearly, China's rapid and sustained economic advancement is starting to pose a challenge to the US's leading economic (and possibly political) role in Africa, especially as Western economies are trapped in a prolonged economic recession which was triggered by US sub-prime mortgages.

There is, of course, a great deal of uncertainty pertaining to the nature of US-China relations $v i s$-à-vis the African continent in the years to come. China's entry into Africa may gradually change the geo-politics and geo-economics of the African region, but the US (and its Western allies) is likely to maintain its high level of economic and political presence in Africa and stay as one of its key development partners for a long time to come. A more fundamental issue is that China's emergence as an economic superpower requires a difficult adjustment for the US. Since launching the policy of "open and reform" in the late 1970s with the overall aim to encourage the modernization of the Chinese economy while maintaining an at least nominally socialist structure, China has achieved levels of economic growth that were nothing less than miraculous. From 1978 to 2006, the real GDP has been growing by 9,6\% annually (Yeoh \& Loh, 2008, p. 3). It is forecasted that by the middle of the twentyfirst century, China's economy will surpass the US economy in size, although its per capita income will still be much lower than that in the US. China has surpassed the US as the number one destination for foreign investment and number one exporter of information technology products. China has the largest foreign reserves in the world, over 1 US\$ trillion. China is the largest consumer of steel and cement. Furthermore, the US depends on China to finance its huge government debt (Shirk, 2008, pp. 5-6). As China's economy has been growing at a double digit level of growth in the last two decades, no one can expect the 
nation to be spending less and remain docile in the military realm. As China grows richer, it will build its military and political strength. Inevitably, as China moves up the economic and technological ladder, it will compete with the US and expand its global reach (as is the case in Africa). But a much graver or serious danger is that as China rises in power, the US will misread and mishandle it leading to a hostile relationship. History teaches us that rising powers are likely to provoke conflict. According to the power transition theory, the largest wars or conflicts arise from challenges to the top position in the status hierarchy, when a rising power is surpassing or threatening to surpass the most powerful state (Goldstein \& Pevehouse, 2012, p.57). Are China and the US doomed to become enemies in the twentyfirst century? or will the US put in place 'preventive' strategies to stop or contain the rise of China before it becomes too great a threat. Recent events seem to indicate such a scenario. Increasing competition is evident in Africa between China on the one hand, and the United States, on the other. Earlier in 2012, the US Secretary for State Hillary Clinton launched an 11-day tour of Africa by contrasting the US's commitment to democracy with China's focus on exploitation. Clinton remarked that the US unlike other states "will stand up for democracy and universal human rights even when it might be easier to look the other way and keep the resources flowing"(Mail \& Guardian, August 2, 2012). Although the US secretary of state did not mention any country by name, her remarks were widely interpreted as a swipe at China, which overtook the US as Africa's largest trading partner in 2009. As mentioned earlier, resource-hungry China is often castigated for turning a blind eye to dictatorships and human rights in its partnerships with African states such as Angola, and Sudan. Unsurprisingly, China responded shortly afterwards when its Ambassador to South Africa Xian Xuejun,criticised "some western politicians and media [who] tend to make irresponsible remarks on China-Africa relations, attempting to mess up our co-operation." (Mail \& Guardian, August 2, 2012). This competition or rivalry makes the development agenda for Africa more difficult/ of effective regimes for managing the sea and its resources more difficult.

The above exchange between the US and China show that conflicts are caused by misperceptions, that is, one country interpreting the behavior of another in the most threatening terms. As noted by Shirk (2008, p.10) the risk of misperceptions between China and the US is heightened because we live in a uni-polar world in which the power gap between the dominant power or hegemon, the US, and other countries is the largest ever in history. Today, the US sees the rise of China as a direct threat to the country's predominance or primacy in the world. In a way, China's rulers confront a difficult predicament in dealing with the US because on the other hand, China's success depends on cooperation with the US. Historical experience prove that a latecomer power can only eventually rise through cooperation with the dominant power in the international system. And China perceives the US as the one power that can block its rise to greatness and influence. Acutely conscious that its rapid rise leads other countries to view it as a threat, China's diplomats have worked hard to build an image of China as a good global citizen and regional neighbor. Despite the current weakness of the US dollar and the uncertainties of the US economy, China, still does not rival the US as a global power in terms of national wealth per capita or in military 
strength, nor is it likely to do so in the foreseeable future. However, China's multi-polar foreign policy is well adapted to a global situation in which it must cooperate with its partners rather than attempt to dominate them (Womack, 2009, p. 2). As corroborated by Tull (2006), China has "advanced the concept of multi-polarity, defined as the construction of more or less flexible alliances to contain every form of hegemony and to build a new and just international order" (p. 461). As part of its multi-polarity strategy, China has reached out to non-Western countries to bolster its international position vis-à-vis the US. Moreover, China's strategic position as United Nations Security Council veto-wielding power has bolstered its clout as a potential leader of the developing world in international affairs, thus, enabling her to push for her policy of multi-polarity. The creation of BRICS as a bulwark against Western paternalism in international affairs is ample demonstration of the success of China's policy of multi-polarity. After all, international relations theory predicts that peace is best preserved by a relatively equal power distribution (multi-polarity) because in such an environment "no country has an opportunity to win easily" (Goldstein \& Pevehouse, 2012, p. 57).

As rightly observed by Tull (2006), China's "undeniable appeal to African states, notably as a trading partner, is the flipside of their fading economic importance to the West (p. 471). Unsurprisingly, asignificant number of African policy makers and academics appear to regard China as both an appealing economic model worth emulating and a potential catalyst for political and socio-economic development. In no small measure, theyconceptualisethe growing South-South cooperation as a historical and strategic opportunity for Africa's states to escape the neo-colonial ties to the West. And China's African policyhas tapped into this hope with devastating efficiency. And yet, it is not evident that Sino-African economic relations differ significantly from Western- African trade relations; nor is it clear that China's engagement will substantially enhance Africa's development prospects. In other words, the jury is still out on the implications of Sino-African economic relations.

As demonstrated clearly in this essay, the US is deeply concerned by an apparent shift in the balance of power in Africa created by an emerging Sino-African strategic partnership. According to $\mathrm{Ng}$ (2012), Western criticisms of China's engagement policy in Africa have failed to make an impact on the continent, for three reasons. Firstly, Western states have failed to demonstrate how the values of human rights and good governance can lead to real economic growth in Africa. Furthermore, in this area, the key argument for democratization and commitments to human rights as necessary parts of good governance is unevenly applied, not effectively communicated, and economically intangible. Aware of these weaknesses, the US Secretary of State Hillary Clinton during her visit to Africa in 2012 conceded in her speech when she said the US "has not always done the best job promoting and explaining what we mean" (Ng, 2012, p. 2). Nonetheless, for the democratisation argument to gain real currency and mileage it will take more than just good public relations. In this regard, the socalled democratic African states (and this in itself is a debatable issue), must economically perform visibly better than their more undemocratic neighbours. It is important to stress that this has not yet occurred. Until then, the democratisation argument remains a moral 
argument. The second factor that has weakened Western criticism of China's Africa policy is that too often, Western development assistance or aid has not had sufficient impact ( $\mathrm{Ng}$, 2012). The management and disbursement of Western aid has not been impressive. In essence, aid has not translated in economic development. Aside from losses to corruption, much of aid promised simply does not reach its intended beneficiaries in Africa in monetary form. In reality most of the aid funds are taken up by companies from the donor state. For instance, two-thirds of American food aid in 2010-11 went to just three American firms (who were then given the contracts to ship food stuffs to poor countries) according to data uncovered by a British newspaper $(\mathrm{Ng}, 2012)$. Not surprisingly, aid critics have lambasted the habit of aid money going to domestic companies of the donor state. In contrast, as demonstrated earlier, China's aid largely consists of in-kind infrastructural developments such as power plants, dams, roads, illustrate Beijing's faith in the role of the African state to overcome development obstacles. As stated by $\mathrm{Ng}$ (2012), the third factor is the structural and institutional differences of the Western and Chinese modus operandi in Africa. China, with its vast array of state-linked companies, is able to direct external investment in a more coordinated and direct manner. For example, China's multiple national oil firms, both stateowned and privately-owned, rarely overlap or compete with each other in their overseas ventures and pursuits. Without doubt, the competitive advantage of putting state enterprises at the disposal of foreign policy is difficult to match for the free market economies of the West. Institutionally, the crucial role FOCAC plays as an intergovernmental platform, enables China to maintainBeijing's centrality on the African agenda. Given these strategic advantages, it is not difficult to understand the generally positive image China enjoys with African elites.

In view of the above challenges, Western criticisms of China's Africa policy will continue to lack any significant impact in Africa. Most crucially, as suggested by Ng (2012) there are major structural differences between the US and China in their engagement with Africa that significantly affect the nature of relations between these parties, and in which China currently has the upper hand. If US and European firms want the same access to African natural resources, they might have to behave a bit more like Chinese companies that work closely with their government in making promises of development and infrastructure (Mail \& Guardian, 2011, 24 October). Ultimately, Africa stands to benefit more as the great powers compete with each other over Africa's untapped wealth. So far, however, China's leaders have demonstrated that have a full understanding of the priorities of African development as reflected in China's recent rise in the continent.

\section{Other Emerging Concerns}

The Chinese model of aid is not infallible. It has its fair share of challenges. The generous aid and grants received by African countries from Beijing, though not bound to political conditions are, however, tied to the use of Chinese firms, equipment and contract workers. In Zambia, as elsewhere, one of the major concerns about the China's approach is the large 
number of unskilled Chineselabourers brought in to work on the mines and construction sites (Mail \& Guardian, 27 July, 2012). There are also serious environmental concerns about Chinese investments. For instance, a study done on Chinese aid to Ethiopia by the African Forum on Debt and Development, citelow or undeveloped environmental, health and safety standards in several Chinese investment projects (Mail \& Guardian, 27 July, 2012).The real challenge of Chinese expansion into Africa lies in the environmental implications, much more so than today's questions and concerns about job loss and trade deficits. The environmental implications - the cost of environmental degradation and resource depletion in Africa, have the potential to create a range of social, political and economic challenges within Africa. This would mean that real or sustainable economic growth would besignificantlyaffected. Certainly, environmentally unfriendly practices will exert a profoundly negative impact on African economies. Africa's political leadership though aware of environmental challenges, they should find a politically acceptable balance between the need to continue economic relations with China and delivering economic growth while at the same time addressing environmental challenges. Unfortunately, as pointed out earlier, most African host governments lack the stamina or, at times, the will to highlight these issues in their dealings with China.

Media reports have been unkind to China's engagement with Africa. Several media players have highlighted incidents of mistreatment of workers by Chinese firms in several African countries across the continent, including Uganda, Zambia and Zimbabwe. However, these challenges are neither new nor exclusive to China's particular presence. To be fair to China, very often China's activities in Africa are labelled negatively by media platforms while they overlook other investors' malpractices and excesses. It could be argued that many of the criticisms levelled at China are in fact reflective of the deeper culture of exploitation of the continent's resources by all major global actors. As rightly put by Hejoo Kim, research analyst at Stellenbosch University's Centre for Chinese Studies, the vested interests of colonial powers, around which global economic structures have been built, are founded on exploitative dynamics that often pass as legitimate simply because they are more deeply entrenched (Mail \& Guardian, 27 July, 2012).

As Beijing firmly sets its footprint across Africa, there are many who question the strategic intentions of its global policy on this continent. Undeniably, deepening China-Africa relations have created a precarious tug-of-war between the US and China, because the interests of China are fundamentally at odds with those of Western donors, whose hegemony is threatened by China's expanding dominance.Driven by a desire to obtain sources of raw materials and energy for China's continuing economic growth and open up new export markets, Chinese penetration into Africa is attracting more and more attention from policymakers and elites in the West (Taylor, 2006, p. 937). Increasingly, Africa is caught in the middle of this complex power struggle.Therefore, a more pressing concern would be whether African countries would be forced to choose between Washington and Beijing. However, as noted by Chigunta "there is no difference between China and the West in terms of what motivates them to be involved in Africa - mineral resources and fuel"(Mail 
\& Guardian, 27 July, 2012). Not surprisingly, The tension between these competing powers which is primarily driven by oil diplomacy is slowly getting out of hand as demonstrated by Clinton's cheeky remarks. In an attempt to overcome their economic and energy crises, the two global powers are increasingly looking more towards Africa's unexplored mineral and energy resources. In addition to long-time energy giants such as Angola, Nigeria and Libya - all of which have close ties with China - recent massive discoveries of oil and gas reserves along the East African coast have upped the stakes in the renewed 'scramble for Africa'. (Mail \& Guardian, 27 July, 2012). In an April 2011 interview, Paul Craig Roberts, a former senior US Treasury official asserted that the NATO alliance's support to the Libyan rebellion had one major aim: "to eliminate China from the Mediterranean" and "looking to Africa as a future energy source" (Mail \& Guardian, 27 July, 2012). In addition Roberts indicated that the US is countering China by organising the United States African Command (AFRICOM) which Gaddafi snubbed. The recent rapid expansion of AFRICOM activities over the past year, particularly in resource-rich countries in Central and Eastern Africa and the turbulent Sahara desert, appears to lend credence to this notion of a "new scramble for Africa'. It is increasingly becoming clear that one of the most significant consequences of growing Sino-African relations might be to position the continent as a contested zone for US-China oil wars. It should be pointed out that any worseningof great power rivalry may erode growing African unity by dividing African countries along two axis, that is, proWestern and Pro-Beijing.

\section{So What is to be Done?}

Though the entry of China into Africa has brought a new optimism and new capital flows into the continent, challenges remain immense. As China's involvement in Africa accelerates, however, more and more questions have been asked about China's tactics and strategies in its quest for resources in Africa. Rwandan president Paul Kagame observed that until African countries achieve real unity of purpose no foreign involvement in the continent (be it from the West or China) will lead to long-term benefit for African countries (Mail \& Guardian, 27 July, 2012). Whilst the characterisation of Africa and China as partners may arguably have some truth if viewed in comparison to traditional donor dynamics, the partnership, however, remains akin to that of a horse and a rider. As aptly captured by Chigunta:
Africa has historically been the horse. The Western rider was very brutal, always beating the horse, whereas the Chinese rider is more subtle, is giving carrots, to get the horse to take him to where the resources are. Either way, at the end of the day, Africa gets a raw deal (Mail \& Guardian, The rise of ChinAfrica, 17 July, 2012).

The foregoing interpretation has resulted in growing concern that the nature of China's engagement in Africa may have the potential to undermine rather than facilitate its growth 
and long term sustainable development.The situation is compounded by the sad reality that many African leaders shy away from criticism because they admire the Chinese economy. They are besotted and fascinated by the Chinese state-led capitalist model, which they believe is the answer to economic growth for developing countries. Achieving doubledigit growth without embracing democracy is an attractive option for many of these leaders. Understandably, as power shifts from the West to the East, African leaders can ill afford to be seen to be anti-Beijing. As African scholars and policymakers grapple with the competing perspectives or positions and seek answers to the question of just what are the impacts and sustained benefits of China's Africa's policy, perhaps the answer lies in "how African leaders engage with China, how they define their business relationships, and manage their political interactions" (Ramburuth, Buatsi, \& Owusu, 2010, p.157). It also lies in just how effectively African leaders are able to leverage the benefits of the growing economic partnership with China.Given that China's presence in Africa is here to stay, engagement with Beijing over such issues is the only practical strategy to take. Only through such serious engagements can the tone of China's Africa policy be transformed into something more tangible and positive for Africa and its peoples. The next Forum on ChinaAfrica Cooperation would be a good starting point for this dialogue to begin in earnest.One should not bet against Africa's ability to overcome its development challenges yet.

\section{Concluding Remarks}

What are the implications of China's entry into Africa? There are mixed reactions on the continent. In its review of the debate over whether these impacts have on balance been positive or negative for the continent, this paper argues that those who emphasise the positive economic impacts of China have been over-optimistic and underplay some of the negative impacts associated with China's forays into Africa. However, the big picture so far is one in which Sino-African economic relations are widely unbalanced and tend to replicate Africa's lop-sided relationships with the West - a relationship Beijing so vividly claims to differ from. Consequently, Africa's marginal place in the global economic system, defined by its "limited value as a provider of mineral resources, may in effect be perpetuated by the fact that China's economic interests in Africa do not differ substantially from those of Western states" (Tull, 2006, p. 476). Ultimately, Chinese foreign policy in Africa and elsewhere is, like all other countries' foreign policies, self-serving and based on national economic and strategic considerations. In this respect, China is no different from others. Unsurprisingly, relations between the United States and China based on strong economic ties are slowly withering and fading in an atmosphere of mutual hostility following increased Chinese forays into Africa, a continent that has traditionally been a Western sphere of influence. Certainly, Africa is of great strategic importance to the US and her Western partners. The same holds for China. By quietly offering alternatives to aid-receiving African countries, China has been effective in weakening the bargaining position of Western donors. The resulting tensions between China and the US over the former's success in Africa underscore the urgency of reforming the Western model of aid. China is fast emerging as a major 
economic and political player in an increasingly complex global environment. Although the United States is the central world power or superpower, global interactions are not entirely mediated through the center. For every country in the world, China now looms on the horizon as a major opportunity and challenge. It has become one of the major nodes in a multi-polar world. However, Africa needs to explore the dynamics and avenues of how to create a more enabling environment and devise empowering strategies to effectively engage China (and other major donors) and participate in the global economy. Certainly, a more pro-active response is vital if Africa is to benefit from China's scramble for its resources.

\section{References}

Akugizibwe, P. (2012, July 17). The rise of China Africa. Mail \& Guardian.

Blankert, J. W. (2009). China rising: Will the west be able to cope? New Jersey: World Scientific.

Brahm, L. J. (1996). China as No. 1: The new superpower takes centre stage. Singapore: BH Asia.

Friedberg, A. L. (2005). The future of U.S.-China relations: Is conflict inevitable? International Security, 30(2) Autumn, pp. 7-45.

Friedman, T. L. (2006). The first law of Geo-politics. Foreign Policy. May/June.

Goldstein, J. S., \& Pevehouse, J. C. (2012). International relations (10th ed.). Boston: Pearson.

Louw-Vaudran, L. (2012, July 27). Africa buys into China's generosity. Mail \& Guardian.

Ng, J. (2012). Great power rivalry in Africa: Economic engagement holds key. RSIS Commentary, No. 153/2012.

Polgreen, L. (2009, March 26). As Chinese investments in Africa drop, hope sinks. International Herald Tribune.

Sautman, B., \& Y. Hairong. (2007). Friends and interests: China's distinctive links with Africa. African Studies Review, 50(3), 75-114.

Smith, D. (2012, August 2). Hillary Clinton kicks off African tour with swipe at China. Mail \& Guardian.

Tammen, Ronald L . (2006). The impact of Asia on world politics: China and India options for the United States. International Studies Review, 8(4), 563-580. 
Taylor, I.(2006). China's oil diplomacy in Africa. International Affairs (Royal Institute of International Affairs 1944-), 82(5), 937-959.

Tull, D. M. (2006). China's engagement in Africa: Scope, significance and consequences. The Journal of Modern African Studies, 44(3), 459-479.

United States Department of Commerce US Census Bureau. (2012). Retrieved from http:// www.census.gov/foreign-trade/.

Yeoh, E. K., \& Loh, J. H-K. (2008). China in the world: Contemporary issues and perspectives. Kuala Lumpur: Institute of China Studies.

Womack, B. (2009). China between region and world. The China Journal, 61, 1-20. 
